\section{Insect viruses}

Virus-Insect Relationships. By Kenneth M. Smith. Pp. viii +291 . (Longman: London and New York, 1976.) £11.

A NEW BOOK on insect viruses is a rare and welcome event for those who work in this area, so a first reaction to it is naturally one of enthusiastic interest. This book is a well produced volume, nicely laid out and printed in a clear easily read type. There are many illustrations but most of the electron micrographs are marred by their flat grey tones. It is a pity that closer examination soon tempers this first impression. Some fears are aroused by certain comments in the preface: "This book has been written by one of the few remaining old-fashioned virologists" and "detailed accounts of the chemical nature of the viruses and their molecular biology have been omitted". Is this an apology for an incomplete or outdated treatise?

The book is divided into two parts, one giving an account of the types of virus and virus disease affecting insects, the other discussing more general aspects such as infection and replication. Although there are advantages to such a layout, it does mean that repetition occurs and narrative lacks cohesion. The further division of the chapters in the first part of the book into a general account of the virus group followed by descriptions of specific viruses was illadvised. Both repetition and contradiction occur as a result. The general account component of each chapter decreases progressively from two and a half pages in chapter 1 to four sentences in chapter 7 so possibly the author by then had appreciated the difficulties that this approach creates. The book has other structural peculiarities. Just one example is the grouping together of parvoviruses and picornaviruses in one chapter (with a short general introductory account dealing with parvoviruses only), whereas viruses of the honey bee and Drosophila species are deemed worthy of a separate chapter despite the fact that most of them are small spherical RNA-containing viruses anyway.

The chapters in this first part of the book describe the various groups of insect viruses mainly from a morphological standpoint, with only spasmodic attempts to include relevant biophysical or biochemical data. More recent efforts in insect virus research, such as the definition of methods and criteria for identifying the large number of virus isolates from different insects more reliably than by naming the host insect, are given scant attention. Not only are such recent data omitted but certain accounts also seem outdated conceptually and there are several examples quoted of observations ur hypotheses which would not now find great support. There are some errors also. For example, the $1.38 \%$ DNA quoted for one insect poxvirus has since been corrected to nearer $5 \%$, and Fig. 5.6 is in fact a picture of Wiseana cervinata iridescent virus and not that of Costelytra zealandica.

In the second part of the book the chapters on serology, nucleic acids and tissue culture in particular are poorly done. Similarly the account of possible hazards in applying insect viruses as pesticides does not do justice to the amount of time and effort spent on this topic in the last three years. Surprisingly it is only in this chapter that one can find any mention of the epizootiology of insect virus diseases. I am surprised also to find staining methods for optical microscopy included as a separate chapter when little effort has been made to describe laboratory techniques elsewhere. For example, the chapter on insect cell culture gives no details of available cell lines or media (in contrast to the chapter on insect rearing where details of synthetic diets are provided) and the reader is referred to somewhat out-dated sources of information.

Two chapters are included on vectors of viruses. The one on "Insects and other arthropods as vectors of plant viruses" is a useful general account, although many plant virologists will be surprised to read that semi-persistent or

\section{Iron-sulphur proteins}

Iron-Sulfur Proteins. Vol. 3 : Structure and Metabolic Mechanisms. Edited by W. Lovenberg. Pp. xiv +443 . (Academic: New York and London, 1977.) $\$ 39.50 ; £ 28.05$.

SINCE the publication of volumes 1 and 2 in this definitive series in 1973 a number of significant advances have been made in the study of iron-sulphur proteins. These are reviewed in this volume which again is a 'must' for anyone interested in the biology and chemistry of ironsulphur proteins.

Beinert's chapter on the iron-sulphur centres of the mitochondrial electron transfer system covers "those developments of the last five years that have made the cytochromes minority constituents". The multiplicity and diversity of iron-sulphur centres makes it necessary to have an electron paramagnetic resonance apparatus to study electron transport in mitochondria. It is a pity that the iron-sulphur centres in photosynthetic membranes were not dealt with similarly. circulative viruses show no latent period in the vector and do not survive after a moult. One confusing aspect of this chapter is that its subdivision by headings of different type face and size seems quite illogical. The chapter on "Insects and other arthropods as vectors of animal viruses" is of little value. It is woefully brief for a topic of this magnitude and importance, and the examples described appear to have been chosen at random. Both of these accounts seem rather out of place in the book, encroaching as they do on other major areas of virology, and they should perhaps have been given a separate section at the end.

The impression left after reading this book is that sadly it is an opportunity missed. It is quite uncritical and often strangely unbalanced in that examples of work have been selected for description, and others excluded, apparently without valid reason. Insect virology has become a more challenging and exciting subject in the last five years. The book conveys little of this to the uninformed reader. To the specialist it is a disappointment. But this book has no competitors and therefore it has some value and usefulness simply because it is a modern text on insect viruses. As such it will find a place on library shelves as a teaching aid and a reference source. We deserved better.

K. A. Harrap

K. A. Harrap is Head of the Virology Section at the NERC Unit of Invertebrate Virology, Oxford, UK.

The enzymology of nitrogenase has advanced significantly and is excellently reviewed by Orme-Johnson. The genetics of the nitrogen-fixing (nif) gene and the regulation of these genes is the subject of Valentine's chapter. The transfer of nif genes to non-nitrogen-fixing organisms is an exciting possibility for the future.

Mössbauer spectroscopy has been crucial in the understanding of the electron transfer properties of the ironsulphur centres. Two chapters by Cammack, Dickson and Johnson, and by Debrunner et al. review the evidence which has been used to adduce structures of the $1 \mathrm{Fe}, 2 \mathrm{Fe}$ and $4 \mathrm{Fe}$ centres, and help confirm X-ray evidence discussed separately by Carter.

Finally, the chapter by Holm and Ibers on synthetic analogues of the active sites of iron-sulphur proteins describes the status of their work. Holm's group has synthesised analogues of $1 \mathrm{Fe}, 2 \mathrm{Fe}$ and $4 \mathrm{Fe}$ centres. The chemical and physical properties of these centres are summarised, and make beautiful reading. D. O. Hall

D. O. Hall is Professor of Biology in the School of Biological Sciences at King's College, University of London, $U K$. 